\title{
THE DAWN OF A NEW ERA ${ }^{1}$ ?: AUSTRALIAN LIBRARY \& INFORMATION STUDIES $^{2}$ (LIS) RESEARCHERS FURTHER RANKING OF LIS JOURNALS
}

\author{
Associate Professor Kerry Smith, PhD \\ Head, Dept Information Studies \\ Curtin University of Technology \\ GPO Box U1987 \\ Perth Western Australia 6845 \\ E-mail: k.smith@curtin.edu.au
}

\begin{abstract}
The Australian federal government's Excellence in Research Australian (ERA) (Excellence in research (ERA), 2009) policy initiative has given Australian LIS researchers the opportunity to review their listings of preferred journal titles that will be a component of measured research activity in the new federal government funding regimes. The Australian research environment, and university reliance on ranking meant that the importance of ranking journal titles could not be ignored. The ranking of journal titles as submitted to the Research Quality Framework (RQF) exercise in 2007-8, was reviewed in a tight timeframe with a collegial response to calls for feedback. The results are reported and the anomaly of the place of Australian LIS in the Field of Research (FoR) category as assigned by the Australian Bureau of Statistics is discussed, as is the potential relevance of this categorisation regarding the choice of journal titles by these members of the LIS discipline
\end{abstract}

\section{Introduction}

As reported by Smith \& Middleton (2009), the Australian library and information academic community undertook a significant project in 2007-8 to meet the requirement of the forerunner to the Australian federal government's Excellence in Research Australian (ERA) policy initiative, the Research Quality Framework (RQF), that the Australian LIS researcher community rank the journals they use. It was also noted in this paper that the list as submitted was not perfect and that if another opportunity arose, amendments should be made.

The opportunity to amend the RQF journal list presented itself in the second half of 2009 when the Australian Library and Information Association (ALIA) was contacted by the Australian Research Council's (ARC) ERA office to check progress on a revised list. Concurrently, this author was contacted by the coordinator of the Australian and New Zealand Standard Research Classification (ANZSRC) FoR code 08 journal listing process being undertaken by Computing Research and Education Association (CoRE). Code 08: Information and Computing Sciences, includes Library and Information Studies under the code 0807. As with the RQF exercise, CoRE again decided to allow the Australia LIS profession to work out their journal listings independent of parallel work by CoRE on the

\footnotetext{
${ }^{1}$ Excellence in Research Australia - see: http://www.arc.gov.au/era

2 "Information science" is a term widely used internationally, whereas "information studies" is the term more commonly used in Australia.
} 
same project. CoRE would then absorb the Australian LIS journal list for 0807 into its final listing for 08. The ALIA through its Research Committee accepted the opportunity to revise the LIS journal list. The profession was also asked whether or not it wished to rank conferences using the same methodologies and definitions, as this would be the practice of the main CoRE parties.

Although the ERA discussions and the ERA trials in the clusters of Physical, Chemical and Earth Sciences and Humanities and Creative Arts in mid 2009 did not only emphasise citations, it was evident that citations remain an important component of the way in which research will be measured in this new research performance environment in Australia. The first step in this process was a trial round of the ERA process for the clusters of Physical, Chemical and Earth Sciences, and Humanities and Creative Arts, with LIS as explained further on, appearing in neither cluster. However these evaluations would inform future work on Australia's research performance evaluation and were "informed by three broad categories of indicators:

1. Indicators of research quality

Research quality is considered on the basis of ranked outlets, citation analysis and peerreviewed Australian and international research income. Peer review is also incorporated where necessary.

2. Indicators of research volume and activity.

Research volume and activity is considered on the basis of total research outputs and research income within the context of the eligible researcher profile.

3. Indicators of research application Applied research is considered on the basis of research commercialization income and other applied measures" (ARC, 2009a).

The amount of background data gathering required by the trial was significant with Australia's university research departments allocating considerable resources to gather data on the research performance of their academics under the guidelines provided by the relevant government departments overseeing the projects. Very few library and information studies schools were included in this trial since, in the eyes of their host universities, the research performance of staff was not considered of adequate calibre to conform to the guidelines as set in the trial by the ARC. Additionally, the categorisation of LIS in the general Field of Research (FoR) of 0807 with Computing precluded the inclusion of this FoR in the trial categories.

In tandem with the trial was the finalization of a national journal and conference ranking exercise by Australia's academics. As the ranking of conferences was to be discipline specific, the Australian LIS professions decided quite early that its discipline would not be ranking them. Nevertheless, participation in the ranking of journal titles proceeded.

Ranking of research takes on a new dimension when so many of Australia's university senior managers rely heavily on the position of their institution in league tables such as Jiao Tong (Healy, 2008). The regular release of revised rankings for this table is eagerly awaited since "Jiao Tong placements increasingly are seen as an important measure of a nation's economic health and competitiveness” (Marginson as reported by Healy, 2008, p. 25). 
Clunies Ross (2008) argues that the new system of metrics needs to be more flexible for the sake of scholars, a matter also shown in earlier work undertaken by this author's $\mathrm{PhD}$ (Smith, 2004, Smith \& Marinova, 2003a, b) that recognised that while citation counts provided an indicator of research performance, it was also discovered that there was much more to the research process than publication and its perceived measurement of success through citations and bibliometrics. Clunies Ross's argues that the research productivity of academics in different clusters is different and it would seem that this and other pleas for some flexibility had been in some part, listened to. It is heartening to see that the creative arts, for example, has gained recognition for research outputs and that mechanisms are being established on how such research outputs as "original creative works" to include live and recorded performances, rendered and curated works, might be measured (ARC, 2009a).

\section{Australian LIS researcher involvement in the ERA agenda}

There is no doubt that a number of Australia's academic libraries and librarians are gearing up to provide more targeted services to their host institution's researchers. Searle (2009) reports on research data management directions at Monash University in order to "promote better management and re-use of data created by research" (p. 27). She refers to changes in the "policy landscape" (p. 27) and they way in which these have opened up possibilities for academic libraries. There are many ways in which this can happen, not only in the realm of data management as one aspect being practised at Monash University, but also assisting academics with the provision of statistics on research performance and impact as described by Drummond \& Wartho (2009) at the University of New South Wales Library. It is the use of citations that has prompted studies by Australian LIS research colleagues Haddow and Genoni (2009), on humanities journals, and of Australian LIS academics and practitioners by Willard, Kennan, Wilson \& White (2008).

Willard et al. (2008) acknowledged that scholarly communication by their subject group entailed more than publishing, but they identified the importance of publishing in refereed journals as an important component. They cited Butler's (2003, a \& b) suggestion "that there is also a direct relationship between the growth in publication numbers and the Australian university funding regimes" (p. 67). Indeed it is the funding for Australian universities through the ERA initiative that drove this present study. Willard et al. downloaded records from a citation database for the period 1975 to 2006 and analysed the and in doing so acknowledged that the reliance on a citation database was a major limitation to the study even though the method included journals in the LIS discipline area and all publications with the geographical location of Australia and recognised that none of the refereed Australian LIS journals were covered at that time by Thomson ISI the citation database supplier. They found that for the period studied, there was: a steady increase in journal publication, an increase in co-authorship such that for the period 1975-1990 there was "no difference in the average number of authors per paper” (pp. 71-2), and that the increase in co-authorship occurred after 1990. They also found an increase in the raw numbers of publications by Australian LIS academics over the period and a decrease in the raw number of publications by Australian LIS practitioners for the same period. Additionally they noted that "the percentage of 
publications by LIS academics and by LIS practitioners in IS\&LS [information science/studies \& library science/studies] journals has dropped” (p. 74).

While it might be believed that positioning in the FoR08 restricts the outputs that the Australian LIS community can claim, the finding by Willard et al. (2008) of the drop in publication in LIS journals by Australian LIS academics could be instructive. Just where they might be publishing is the subject of further work by Willard et al. The parent discipline for the FoR 08 is Information and computing sciences and this covers the following sub disciplines:

0801 - artificial intelligence and image processing;

0802 - computational theory and mathematics;

0803 - computer software;

0804 - data format;

0805 - distributed computing;

0806 - information systems;

0807 - library and information studies;

0899 - other information and computing sciences (ANZRC, 2008).

It would appear that when the discussions for the FoR review were underway, the impression gained by most of the Australian LIS researchers was that, in the context of the then RQF, the FoR would be independent of any RQF assessment since the RQF template for research assessment was to be discipline by discipline. So once the ERA initiative was announced, it seems that almost by stealth, the FoR codes became the easy way for ERA to assign disciplines to categories. Consequently LIS remains within FoR 08, at 0807. It needs to be noted that there remain a number of LIS researchers and educators who are not happy with this coding, but there appears to be little that can be done to have the discipline re-categorised, at this stage. It is interesting to note these various facets as part of the research dimension for today's Australian LIS researcher.

\section{The ERA journal ranking process}

In a business model that is practiced in many Australian universities and driven by performance that is measured by outputs, outcomes and ranking on the local, national and global scales, ranking fits well with the foregoing discussion. Nevertheless the ranking exercise conducted on journal titles was not driven by citations alone. The ARC/ERA requirement was that the titles be listed using a tiered approach that signified the quality of the papers that each journal title contained:

Tier $A^{*}$ - Typically an $A^{*}$ journal would be one of the best in its field or subfield in which to publish and would typically cover the entire field/subfield. Virtually all papers they publish will be of a very high quality. These are journals where most of the work is important (it will really shape the field) and where researchers boast about getting accepted. Acceptance rates would typically be low and the editorial board would be dominated by field leaders, including many from top institutions.

Tier A - The majority of papers in a Tier A journal will be of very high quality. Publishing in an A journal would enhance the author's standing, showing they have real engagement with the global research community and that they have something to say about problems of some significance. Typical signs of an A journal are lowish 
acceptance rates and an editorial board which includes a reasonable fraction of well known researchers from top institutions.

Tier B - Tier B covers journals with a solid, though not outstanding, reputation. Generally, in a Tier B journal, one would expect only a few papers of very high quality. They are often important outlets for the work of PhD students and early career researchers. Typical examples would be regional journals with high acceptance rates, and editorial boards that have few leading researchers from top international institutions.

Tier C - Tier C includes quality, peer reviewed, journals that do not meet the criteria of the higher tiers. (ARC, 2009b).

It was with these qualifications in mind that the review of journal rankings by members of the Australian LIS research community was undertaken.

There were two ranking exercises to be undertaken: the possible ranking of LIS conferences, and the finalisation of the LIS journal rankings. Since the process of ranking of conferences had not been undertaken before, the ALIA Research Committee under the another's leadership undertook the consultations. The first step was to find out from the profession if indeed it wished to do this and the final outcome of the consultation process, undertaken by email though various Australian e-lists, was reported in an email to those lists at the end of September 2009, stating:

\section{Outcome from ALIA Research Committee: ERA and ranking of LIS conferences Dear Colleagues}

Thank you to those who kindly provided comments to the question on whether the LIS field should include ranked peer reviewed conferences as part of ERA.

This is a difficult question with many aspects to consider. The ALIA Research Committee met last week via teleconference to consider the responses we received and to weigh up the options.

The committee has decided to inform the ARC that the LIS field will not be ranking peer reviewed conferences as part of ERA.

As always if you have any questions or require clarification please do not hesitate to contact the ALIA Research Committee.

ALIA Research Committee

\section{Revisiting the LIS Journal rankings}

The ALIA Research Committee's tidying up the ERA LIS 0807 Journal listings as part of the ARC's additional expert review process to further strengthen sector confidence in the List, was a lengthier process. It was first thought that the final list as submitted to the RQF/ERA process in November 2007 would closely align with the list as received from ERA in September 2009. It did not, as shown in Table 1 following. 
Table 1: Summary of LIS journal titles

\begin{tabular}{|l|l|l|l|l|l|l|}
\hline & $\begin{array}{l}\text { Tier } \\
\mathrm{A}^{*}\end{array}$ & Tier A & Tier B & Tier C & $\begin{array}{l}\text { Not } \\
\text { ranked }\end{array}$ & Total \\
\hline $\begin{array}{l}\text { RQF/then } \\
\text { ERA original } \\
\text { list (Smith \& } \\
\text { Middleton } \\
\text { 2009) }\end{array}$ & 10 & 19 & 45 & 75 & 0 & 149 \\
\hline $\begin{array}{l}\text { No. of missing } \\
\text { ALIA titles in } \\
\text { revised ERA } \\
\text { list July 2009 }\end{array}$ & 1 & 6 & 20 & 35 & - & 62 \\
\hline $\begin{array}{l}\text { Total titles in } \\
\text { revised ERA } \\
\text { list July 2009 }\end{array}$ & 13 & $\begin{array}{l}22 \\
\text { (incl. 1 } \\
\text { title } \\
\text { listed } \\
\text { twice) }\end{array}$ & 37 & 70 & 4 & 146 \\
\hline $\begin{array}{l}\text { New titles in } \\
\text { revised ERA } \\
\text { list }\end{array}$ & 4 & 8 & 12 & 41 & - & 65 \\
\hline
\end{tabular}

A hasty interpretation of the numbers in Table 1 might indicate little change in the 2009 ERA LIS journal title listing, but this was not the case. A few of the titles missing from the 2009 ERA journal listing or notated as "new" to a particular tier had been moved by ARC/ERA from one tier to another. The majority of the new ARC/ERA 2009 titles were just that and the title coverage of these new titles indicated an influx of archival, health informatics and computer oriented journals. It is interesting to note that the number of titles missing from the ALIA listing (Smith \& Middleton, 2009) = 62, closely resembled the number of new titles in the ERA 2009 list $=65$, but there was little similarity in titles between the two lists.

An added dimension to this part of the exercise was the requirement by ERA that this task be undertaken by one person who had signed a confidentiality agreement regarding feedback data on the journal listings. The author was that person.

The next steps were decided in consultation with the ALIA Research Committee. Since archives and records management titles were included in the journal listing received from ARC/ERA so the Australian Society of Archivists (ASA) was included in the consultation process. The then Records Management Association of Australasia (RMAA) decided not to participate.

It was now a requirement that ALL journals that appeared on the ARC/ERA list, regardless of their Tier, must undergo some sort of peer review of contributions. On this issue, the ARC advised that they were reasonably relaxed about the level of peer review (i.e. not every title needed to have a double blind peer review requirement), but that there 
must be visible evidence that the title went through some sort of peer review process. This meant that some of the titles that appeared on the current list would need to be removed. Other disciplines who were in discussion with the ARC over the inclusion of non-peer reviewed journals got nowhere with respect their inclusion.

It was also evident that since the work undertaken in 2007-8, the percentage of titles allowed in each Tier had been moving around in some disciplines such that there was now some leeway if the final decision was made to move a title from one level to another and to possibly add others. It will be recalled that the number of titles in each Tier according to the earlier RQF exercise had been very controlled: Tier A* (top 5\%); Tier A (next 15\%); Tier B (next 30\%); and Tier C (bottom 50\%) (Smith \& Middleton, 2009).

The current ARC/ERA 0807 list was reviewed for duplicates, and an attempt was made through a quick web search to locate peer review statements for all titles. This information was noted on a revised ERA 0807 Excel spreadsheet journal list and the revised list was emailed to Australian LIS and archives colleagues. Those titles that were not peer reviewed were marked as such. ALIA Research Committee colleagues would need to locate the peer-review evidence for those titles that were deemed important to them for which no such evidence could be located, and they were also asked to provide peer review statements for titles marked on this list as not, if they believed they were.

A supplementary list of journal titles was attached to the email. This was a list of titles missing from the ERA 0807 list that had appeared on the listing of titles as published in Smith \& Middleton (2009). There were 62 titles on this list and colleagues were again requested to revisit the importance of these missing titles and rank them accordingly for potential inclusion.

Colleagues were requested to make relevant comments on the ERA 0807 Excel spreadsheet list noting changes they required. It was noted that while some titles had been discontinued, they could still be valid for the ARC "reference period" of 2003-2008 once the ERA exercise got underway in 2010. Colleagues were also requested to reply as a group to make the final analysis of the responses less cumbersome. All of this work removed the requirement for completion of the ARC's ERA New Journal Form, as the ARC would take the final feedback that the ALIA Research Committee provided through its liaison with CoRE.

\section{Refereed titles}

The requirement that a journal appear on the final ERA list only if refereed was initiated in the first screening of the titles. Journal websites were trawled for proof of the journal being refereed. The data in the following table summarises the process and the final results once final checks were again made on the Web and also using Ulrich's Periodicals Directory. The extent of this list is instructive as an indication that even when journal titles have their own websites, not all of the information that was required appeared on these websites. The majority of these titles occurred in Tier C. 
Table 2: Non refereed journal titles

\begin{tabular}{|c|c|c|c|}
\hline Journal title not refereed? & Tier & $\begin{array}{l}\text { Peer review } \\
\text { comments after } 1^{\text {st }} \\
\text { check }\end{array}$ & $\begin{array}{l}\text { ALIA Result after } \\
\text { final check }\end{array}$ \\
\hline Library trends & $\mathrm{A}^{*}$ & $\begin{array}{l}\text { Refereeing statement } \\
\text { unclear }\end{array}$ & $\begin{array}{l}\text { Editors advise journal } \\
\text { is refereed and will } \\
\text { amend information to } \\
\text { reflect this }\end{array}$ \\
\hline $\begin{array}{l}\text { The Library: transactions of the } \\
\text { Bibliographical Society }\end{array}$ & $\mathrm{A}^{*}$ & $\begin{array}{l}\text { No evidence of } \\
\text { refereeing }\end{array}$ & $\begin{array}{l}\text { Editors advise journal } \\
\text { is refereed and will } \\
\text { amend information to } \\
\text { reflect this }\end{array}$ \\
\hline Information and Organization & $\mathrm{A}$ & Not refereed? & Refereed. Tier A \\
\hline $\begin{array}{l}\text { Information, Communication and } \\
\text { Society }\end{array}$ & A & Omitted in checking & Refereed. Tier A \\
\hline $\begin{array}{l}\text { International Journal of Medical } \\
\text { Informatics }\end{array}$ & $\mathrm{A}$ & Not stated & Refereed. Tier A \\
\hline $\begin{array}{l}\text { Nauchno-Technicheskoi Informasiyesa } \\
\text { Seriyesa } 1\end{array}$ & $\mathrm{~A}$ & Unable to locate & $\begin{array}{l}\text { Title deleted as non } \\
\text { English language }\end{array}$ \\
\hline Scientometrics & A & Unable to locate & Refereed. Tier A \\
\hline $\begin{array}{l}\text { Archives: Journal of the British Records } \\
\text { Association }\end{array}$ & $\mathrm{B}$ & Not stated & Refereed. Tier B \\
\hline $\begin{array}{l}\text { Information Management (New York, } \\
\text { 1966) }\end{array}$ & $\mathrm{B}$ & $\begin{array}{l}\text { Not stated. ? still } \\
\text { exists }\end{array}$ & $\begin{array}{l}\text { Deleted. Retitled and } \\
\text { new title not refereed }\end{array}$ \\
\hline Information Systems Management & $\mathrm{B}$ & Possibly & Refereed. Tier B \\
\hline Journal of Information Ethics & $\mathrm{B}$ & Unable to locate & Refereed. Tier B \\
\hline Knowledge Organization:... & $\mathrm{B}$ & Not stated & $\begin{array}{l}\text { Refereed. Moved to } \\
\text { Tier A }\end{array}$ \\
\hline Advanced Technology Libraries & $\mathrm{C}$ & Unable to locate & $\begin{array}{l}\text { Deleted. Unable to } \\
\text { locate refereeing } \\
\text { policy }\end{array}$ \\
\hline Arkiv, samhdlle och forskning & $\mathrm{C}$ & Unable to locate & Refereed. Tier C \\
\hline Bibliotheques de France. Bulletin & $\mathrm{C}$ & Unable to locate & $\begin{array}{l}\text { Title deleted as non } \\
\text { English language }\end{array}$ \\
\hline Business Information Review & $\mathrm{C}$ & $\begin{array}{l}\text { No evidence of } \\
\text { refereeing }\end{array}$ & $\begin{array}{l}\text { Title deleted - not } \\
0807\end{array}$ \\
\hline Education Libraries Journal & $\mathrm{C}$ & $\begin{array}{l}\text { Unable to locate } \\
\text { website }\end{array}$ & Refereed. Tier C \\
\hline Informatics for Health and Social Care & $\mathrm{C}$ & Not stated & Refereed. Tier C \\
\hline Information Services \& Use & $\mathrm{C}$ & Not stated & Refereed. Tier C \\
\hline The Information Technologist & $\mathrm{C}$ & Not stated & $\begin{array}{l}\text { Deleted. Unable to } \\
\text { locate refereeing } \\
\text { policy }\end{array}$ \\
\hline $\begin{array}{l}\text { The International Information and } \\
\text { Library Review }\end{array}$ & $\mathrm{C}$ & Not stated & Refereed. Tier C \\
\hline International Journal for Infonomics & $\mathrm{C}$ & Not stated & $\begin{array}{l}\text { Deleted. Unable to } \\
\text { locate refereeing } \\
\text { policy }\end{array}$ \\
\hline Journal of Scholarly Publishing & $\mathrm{C}$ & Not stated & Refereed. Tier C \\
\hline
\end{tabular}




\begin{tabular}{|l|l|l|l|}
\hline Journal title not refereed & Tier & $\begin{array}{l}\text { Peer review } \\
\text { comments after } \mathbf{~ s}^{\text {st }} \\
\text { check }\end{array}$ & $\begin{array}{l}\text { ALIA Result after } \\
\text { final check }\end{array}$ \\
\hline $\begin{array}{l}\text { Journal of Universal Knowledge } \\
\text { Management }\end{array}$ & C & Link not working & Refereed. Tier C \\
\hline Law Library Journal & C & Edited only & Refereed. Tier C \\
\hline Learned Publishing & C & Not stated & $\begin{array}{l}\text { Refereed. Moved to } \\
\text { Tier B }\end{array}$ \\
\hline $\begin{array}{l}\text { Library and Information Science } \\
\text { Library Collections Acquisitions and } \\
\text { Technical Services }\end{array}$ & C & $\begin{array}{l}\text { Unable to locate } \\
\text { website }\end{array}$ & Refereed. Tier C \\
\hline Library Technology Reports & C & Not stated & Refereed. Tier C \\
\hline Online & C & Edited only & Refereed. Tier C \\
\hline $\begin{array}{l}\text { Profesional de la Informacion } \\
\text { C }\end{array}$ & Unable to locate & $\begin{array}{l}\text { Title deleted as non } \\
\text { English language }\end{array}$ \\
\hline $\begin{array}{l}\text { The Scientist: magazine of the life } \\
\text { sciences }\end{array}$ & C & Not evident & $\begin{array}{l}\text { Deleted - title not } \\
\text { 0807 }\end{array}$ \\
\hline
\end{tabular}

Thirty two titles on the original ARC/ERA list required refereeing checks. Of these:

- 2 were from Tier A*

- 5 were each from Tiers A and B, and

- The remaining 20 were from Tier C.

After final checking by both the participants and the author,

- Tier $\mathrm{A}^{*}$ - the owners of the journals reported that the journal websites of the two $\mathrm{A}^{*}$ titles will be amended to reflect the refereeing process;

- Tier A - 4 titles retained, 1 title deleted as non English language;

- Tier B - 3 titles retained, 1 title moved to Tier A, 1 title deleted.

- Tier C - 11 titles retained, 1 title moved to Tier B, 2 titles deleted as non English language, and 6 titles deleted as either not refereed or did not belong in FoR 0807.

The analysis of the final feedback received from all ALIA contributors was undertaken based on the journal tiers, decisions regarding the unranked titles, the appearance of new titles and the results of comments made on the supplementary list of journal titles.

\section{Tier analysis}

Tier A*

There were three titles added to the ARC/ERA list of 13 in the A* category: the journal Archivaria, promoted from Tier A to A*; the title Archival Science: international journal on recorded information which appeared as "unranked" on the original ERA list was ranked A*, and a new title Journal of the Society of Archivists was suggested as an A* title.

Tier A

The final number of titles in Tier A was increased from 22 to 30. 
- The journal Nauchno-Technicheskoi Informasiyesa Seriyesa 1 was deleted because it was not English language and no interest in the title was expressed by the Australian LIS researcher community;

- the title The Australian Library Journal was deleted as it had been entered twice on the ERA list;

- $\quad$ as mentioned above, Archivaria had been promoted to Tier A*.

- Four titles were promoted from Tier B to Tier A: Government Information Quarterly: an international journal of information technology management, policies, and practices, Journal of Informetrics, Knowledge Organization: international journal devoted to concept theory, classification, indexing, and knowledge representation, and Libraries and the Cultural Record: exploring the history of collections of recorded knowledge.

- Two titles were promoted from Tier C to Tier A: Archives and Manuscripts, and Records Management Journal; and

- $\quad$ five new titles were added to Tier A: Collection Management, Information Processing and Management: An International Journal, Information Retrieval, International Journal of Information Management and The Information Society.

Tier B

There was an increase in titles in Tier B from 37 to 48 despite the loss of the 4 titles mentioned above, to Tier A.

- Two titles were deleted - Information Management (New York, 1966): for the information handling as it could not be located on any website or in Ulrich's periodicals directory, and Library Resources and Technical Services because it had been entered twice on the Tier B listing;

- Three titles were promoted from Tier C to Tier B. These were: Journal of Enterprise Information Management, Learned Publishing and Program: Electronic library and information systems.

- Fourteen new titles were added to Tier B: Collection Management, d-Lib Magazine; Education for Information; First Monday; Information and Records Management Annual; Information Resources Management Journal; International Journal on Digital Libraries; Internet Reference Services Quarterly; Internet Research; Journal of Information, Communication and Ethics in Society; Journal of Web Librarianship; Online Information Review; Serials Review and Synergy.

Tier $C$

There was a reduction in the number of titles in Tier $C$ from 70 to 55 . This included the promotion of the two titles mentioned above from Tier $\mathrm{C}$ to Tier $\mathrm{A}$, and three titles from Tier C to Tier B.

- Twelve titles were deleted from the list: 6 were not refereed, 3 were non-English language, 1 was no longer published, 1 was a monograph series and the final title was not relevant to the discipline area.

- $\quad$ Five new titles were added to Tier C: International Journal of Information and Communication Technology Education (IJICTE), International Journal of Information Ethics, Health Information \& Libraries Journal, Journal of 
Government Information now incorporated into , Library Philosophy and Practice and Malaysian Journal of Library and Information science, and

- one title, InterActions (Los Angeles): UCLA journal of education and information studies was moved from "unranked" status to Tier C.

Unranked titles

Two of the four unranked titles remained unranked since they were deemed not relevant to the LIS discipline area. Of the other two titles, one was promoted to Tier A* and the other to Tier $\mathrm{C}$ as mentioned above.

New titles

The ability to add new titles to the submitted ERA list remained and the analysis described in earlier sections of this paper is summarised:

Tier A*: $\quad$ Archival Science: international journal on recorded information which appeared as "unranked" on the original ERA list was ranked A*, one new title Journal of the Society of Archivists was suggested as an A* title.

Tier A: $\quad$ five new titles;

Tier B: $\quad$ fourteen new titles; and

Tier C: $\quad$ five new titles plus one title, InterActions (Los Angeles): UCLA journal of education and information studies was moved from "unranked" status.

\section{Supplementary list}

The analysis of the 62 titles emailed out to all as an additional list of journal titles not appearing on the ARC/ERA list revealed that:

- 2 titles were listed in error as they already appeared on the original ERA list;

- 28 were considered not relevant to the 0807 FoR;

- 9 had ceased publication or information on them could not be located;

- 14 were added to the revised ALIA list as new titles. These were:

o Tier A - 3 titles: Information Retrieval; International Journal of Information Management; Information Society, The International Journal

o Tier B - 7 titles: d-Lib Magazine; Education for Information; First Monday; Information Resources Management Journal; International Journal on Digital Libraries; Online Information Review; Telecommunications Policy.

o Tier C - 4 titles: Health Information and Libraries Journal; International Journal of Information and Communication Technology Education; International Journal of Information Ethics; Journal of Government Information.

- 3 were not refereed;

- 6 titles had no comment made against them, nor were they added to the ERA list

An ALIA deadline of 30th September 2009 was set. Getting the work completed in time to feedback to CoRE by its end of October 2009 deadline was complicated by the author's long service leave commitments. The end of September deadline was met by a number of groups and individuals. It was heartening to realise that colleagues were 
taking the exercise seriously and had consulted widely amongst their peers. This had not always been the case in the earlier RQF iteration of the process.

\section{Refining the ALIA master journal list for final acceptance}

On 17 December 2009, the ARC released their final composite journal listing for a final "sanity check" having "consolidated more than 46,000 expert reviews of over 20,000 journals to develop the draft ERA journal list” (Calder, 2009). It was impressed upon those who received the email that the list remained confidential and was not to be redistributed to colleagues. Again the CoRE team allowed ALIA to manage any final comments for the 0807 listing and requested that ALIA advise them of any changes made. The author was again the reviewer and contact person for this part of the exercise.

The 0807 journal list submitted in Oct 2009 was checked against a draft list emailed by CoRE in January 2010 and against the ARC's Confidential list. Where there was a discrepancy against a title, the decision made for those titles that had been earlier decided upon by the Australian LIS community was re-affirmed. Nevertheless there were 64 titles with issues, the significance of the latter being an apparent neglect by ARC to take up the CoRE suggestions as emailed to ARC back in October 2009. This not only affected the 0807 listings, but also many of the CoRE journal titles, including many that were not of relevance to 0807. This discrepancy was highlighted when the final ALIA 0807 worksheet was emailed both to ARC and CoRE on 25 January 2010, with ARC commenting that the many changes noted by ALIA for 0807 would need to be checked by CoRE first, and CoRE affirming that the original 0807 October 2009 list as emailed by ALIA had been used with very few, if any, changes made to it.

A table was drawn up of the 0807 LIS additional 64 titles and titles for which there was a new issue and this was emailed to Australian LIS research and teaching colleagues on $18^{\text {th }}$ January 2010 for urgent final comment to be incorporated into the list of changes for CoRE and ARC. There were new 16 titles on this new list, 11 of which had not been listed in earlier iterations of the exercise. Nine of these titles were confirmed by LIS colleagues as deletions from the 0807 listing as they were not relevant to the Australian LIS discipline and the remaining two: Interdisciplinary Journal of Information, Knowledge and Management and International Journal of Digital Curation were added as relevant titles to Tiers $\mathrm{C}$ and A respectively. The remaining 5 of these 16 titles contained a disagreement in the Tier listing, often between CoRE and ARC, and confirmation from Australian LIS colleagues was sought on the 0807 preference. This was communicated in the final worksheet. One new title, Scan, a partially refereed journal in teacher librarianship, was added to the list with accompanying comments of support from the Australian teacher librarianship community. This final worksheet as emailed to ARC and CoRE on 25 January 2010 contained comment on the 64 titles with the breakdown of this analysis as shown in Table 3 below. 
Table 3: Analysis of title changes required for 0807

\begin{tabular}{|c|c|c|c|c|}
\hline $\begin{array}{l}\text { ADDED TITLE/S, } \\
\text { OTHER }\end{array}$ & TIER CHANGE & $\begin{array}{l}\text { CONFIRM TITLE } \\
\text { DELETION }\end{array}$ & $\begin{array}{l}\text { CHANGE DUE } \\
\text { TO CoRE/ARC } \\
\text { discrepancy }\end{array}$ & TOTAL \\
\hline 5 & 24 & 27 & 8 & 64 \\
\hline
\end{tabular}

\section{Added titles}

As well as the new title, Scan, and the Interdisciplinary Journal of Information, Knowledge and Management and International Journal of Digital Curation mentioned earlier, the "other" category represents advice to CoRE/ARC on typographical and other recording errors.

\section{Tier change}

The 24 titles in this category required either a verification of Tier as per the CoRE and/or ARC lists, or required reaffirmation that LIS 0807 required a different Tier to that listed by one or both of the other bodies. In the latter instance, the Tier was often bumped down by another FoR, and required confirmation that the amended Tier was of importance to 0807.

\section{Deleted titles}

The majority of deleted titles (27) were because they were not considered by the Australian LIS academic and research community as relevant to the 0807 FoR. These included LIS titles that were not in the English language, some that were niche university library journals, and others that belonged to non related disciplines.

\section{Change due to CoRE/ARC discrepancy}

The 8 titles counted in this category understates the disagreement between the two lists from CoRE and ARC and the resolution of this was left in the hands of CoRE/ARC. It was necessary that Tier assessments be re-reported accurately as per the Tier change category (24 titles) many of which were also a discrepancy between the CoRE and ARC record. The remainder of the titles in the discrepancy category were usually titles missing from the CoRE list that still appeared on the ARC list and it was necessary to confirm these 8 titles and the ranking of them.

\section{Discussion}

The Australian LIS community participated in a wholehearted manner to this re-ranking exercise and it was to be hoped that the resultant modifications and suggestions to the ERA listings would be accepted by CoRE and thus by ARC/ERA. The list was despatched to CoRE by the due date and the author was advised that the Australian LIS list was indeed merged into the CoRE larger journal title list, although "foreign titles were left in since the ARC are trying to add foreign language journals" (Edwards, personal communication, January 27, 2010) and a note that some of the title deletions might not be agreed by the ARC as "these appear to be legitimate refereed journals" (Edwards, personal communication, January 27, 2010). Just how successful the Australian LIS researcher and academic community would be in gaining acceptance of their ARC/ERA journal title recommendations remained to be seen. But it was not for the want of trying. 
The final journal title decisions made by the Australian LIS researcher community were based on the Tier definitions as prescribed by the ARC and it was interesting to note that overall there were few disagreements. Even with the participation by the archival research community, very few titles were in dispute and the decision was made that in their area of expertise, the archivists would know best and their choice was recorded.

It transpired that the final ERA journal ranking list that the Australian LIS research community submitted through ALIA was not accepted in total by the ERA governing body on this matter, the ARC. This was despite evidence and assurances that the parent body supervising the completion and submission to the ARC of the ERA ranked journal lists: FoR08: Information and Computing Science, submitted the ALIA rankings essentially unaltered.

The ARC's process for release of the final list was not transparent. Small comfort might be gained from the fact that a number of other discipline areas were similarly affected (or more precisely disaffected). It is evident that the final decisions of the ARC gave little credence to the importance to national titles. Macauley's (2010) brief analysis of the final run of ALL journal titles in the ARC's final list:

I did a keyword search for Austral* on the complete ERA Journal Title List. Listed below are the A* ranked journals located:

Australasian Journal of Philosophy

Modern Greek Studies (Australia and New Zealand)

While an Australian produced journal doesn't necessarily need to have Australia/Australian/Australasia etc in the title, it is a sad reflection on the lack of respect that has been given to Australian journals in the ERA process (P. Macauley, personal communication, May 3, 2010).

In the case of the ALIA submission, the transfer of the two premier Australian library journal titles: Australian Library Journal and Australian Academic and Research Libraries from ALIA Tier A to ARC/ERA Tier B illustrates the point made by Macauley above.

The 2010 final ARC/ERA list contained the following titles not covered by the ALIA submission:

Tier A: Information Technology \& People.

Tier B: Library Resources and Technical Services and this title was listed twice, Orana, Portal: libraries and the academy.

Tier C: El Profesional de la Informacion, Information Technologist, International Journal for Infonomics, Malaysian Journal of Computer Science, New Zealand Library and Information Management Journal, Online: exploring technology and resources for information professionals, Publishing Research Quarterly, TUGboat.

There was just one title that was on the ALIA list and was not mentioned in the 2010 final ARC/ERA list: International Journal of Information Ethics a new title recommended by ALIA at Tier C. 
There were also discrepancies in the ranking of titles and as an illustration, the situation for Tier $A^{*}$ is shown in Table 4 below. From the data in Table 4, a comparison can be made of the "final" lists of Australian LIS journal title rankings as submitted by ALIA for the top tier (Tier $A^{*}$ ) through the RQF, and later through ERA to the final release of the Tier $A^{*}$ titles from the ARC.

Table 4: Tier A* journal rankings submitted by ALIA

\begin{tabular}{|c|c|c|c|}
\hline Journal title & $\begin{array}{c}\text { ALIA RQF } \\
\text { Tier }\end{array}$ & $\begin{array}{c}\text { ALIA ERA } \\
\text { Tier }\end{array}$ & $\begin{array}{c}\text { ARC FINAL } \\
\text { Tier }\end{array}$ \\
\hline American Archivist & Nil & $\mathrm{A}^{*}$ & $\mathrm{~A}$ \\
\hline $\begin{array}{l}\text { ARIST: Annual Review of Information Science \& } \\
\text { Technology }\end{array}$ & $A^{*}$ & $A^{*}$ & $A^{*}$ \\
\hline $\begin{array}{l}\text { Archival science: international journal on recorded } \\
\text { information }\end{array}$ & Nil & $A^{*}$ & $A^{*}$ \\
\hline Archivaria & Nil & $\mathrm{A}^{*}$ & $\mathrm{~A}^{*}$ \\
\hline Information Processing \& Management & $\mathrm{A}^{*}$ & A & A \\
\hline Information Research & $A^{*}$ & $A^{*}$ & A \\
\hline Journal of Documentation & $\mathrm{A}^{*}$ & $\mathrm{~A}^{*}$ & A \\
\hline Information Systems Research & Nil & $\mathrm{A}^{*}$ & $\mathrm{~A}^{*}$ \\
\hline Journal of Information Science & $\mathrm{A}^{*}$ & $\mathrm{~A}^{*}$ & A \\
\hline $\begin{array}{l}\text { Journal of the American Society for Information } \\
\text { Science and Technology (JASIST) }\end{array}$ & $A^{*}$ & $A^{*}$ & $A^{*}$ \\
\hline Journal of the Society of Archivists & Nil & $\mathrm{A}^{*}$ & $\mathrm{~A}$ \\
\hline Library \& Information Science Research & $\mathrm{A}^{*}$ & $\mathrm{~A}^{*}$ & $\mathrm{~A}^{*}$ \\
\hline (The) Library Quarterly & $\mathrm{A}^{*}$ & $\mathrm{~A}^{*}$ & $\mathrm{~B}$ \\
\hline Library Trends & A* & $\mathrm{A}^{*}$ & $\mathrm{~B}$ \\
\hline Management Science & Nil & $A^{*}$ & $\mathrm{~A}^{*}$ \\
\hline School Library Media Research & A* & $\mathrm{A}^{*}$ & A \\
\hline $\begin{array}{l}\text { The Library: the transactions of the Bibliographical } \\
\text { Society }\end{array}$ & Nil & $A^{*}$ & $A^{*}$ \\
\hline Total A* & 10 & 16 & 8 \\
\hline
\end{tabular}

In terms of raw numbers, the reduction of $16 \mathrm{~A}^{*}$ titles as submitted by ALIA to ERA to the $8 \mathrm{~A} *$ titles, i.e. $50 \%$, released by ERA/ARC is worth noting, particularly as there had been some relaxation in the number of titles per tier from the RQF days. Ten titles were submitted by ALIA to the RQF Tier A* in November 2007. The Australian Society of Archivists requested inclusion of their titles in the ALIA submission for the ERA 2009 round, and this explains the appearance of additional titles in this discipline area to the final 16 titles ranked $A^{*}$ as submitted by ALIA to ARC/ERA. The listing released by the ARC on behalf of ERA in February 2010 contained 8 A* titles. Of the 16 ALIA A* titles submitted to ERA , 8 retained $A *$ status. The remaining ALIA A* titles were downgraded: 6 to Tier A, and 2 to Tier B.

The ARC then advised that the lists were to be revised again in the near future (ARC, 2010), but the mystery as to why the intense commitment of those researchers in the LIS discipline, and others, was essentially ignored in the final analysis and released product, remains. The lack of transparency shown by the ARC has disappointed and angered 
many members of the Australian academic community (e.g. Cockbain, 2010;

Rowbotham, 2010).

The positioning of library and information studies in FoR 08: Information and computing sciences continues to be a topic of discussion amongst the Australian LIS researcher network, with many not happy with this classification. But what of the archivists? The only other possible position for them in the revised ANZRC codes could be in 2102 Curatorial and related studies. Yet they have chosen to be included in with 0807: library and information studies. There is no doubt that a number of the titles that they listed also encompass curatorial and records management emphases. So it would seem that they can be in possibly three places: FoR 0807, and as the ANZRC advice indicates that "archival, repository and related studies is included in Group 2102 Curatorial and related Studies”, whereas records management FoR appears under Division 15 - Commerce, Management, Tourism and Services, 1503: Business and management, 150301 - Business information management (including records, knowledge and information management and intelligence (ANZRC, 2008).

Cowan \& Pember (2008) undertook a study of the top ten professional journals used by recordkeeping professionals in Australasia. Thirty three percent of those who gave a professional affiliation in this study associated themselves with the Australian Society of Archivists. Fourteen percent of the respondents worked solely in the field of archives, and of those working in multiple areas, two thirds worked in archives. Their report of the most widely read recordkeeping journals in their survey is summarised in Table 5 followed by a comment on how this title ranked in the final ERA listing included.

Table 5: Most widely read professional journals by recordkeeping professionals in Australasia (based on data in Cowan \& Pember, 2008, Table 7)

\begin{tabular}{|l|c|c|c|}
\hline JOURNAL TITLE & $\begin{array}{c}\text { PERCENTAGE OF } \\
\text { READERS }\end{array}$ & $\begin{array}{c}\text { AUSTRALIA LIS ERA } \\
\text { RANKING OF TITLE }\end{array}$ & $\begin{array}{c}\text { ARC/ERA RANK } \\
\text { Jan 2010 in 0807 }\end{array}$ \\
\hline Informaa Quarterly & $84.1 \%$ & $\mathrm{C}$ & $\mathrm{C}$ \\
\hline $\begin{array}{l}\text { Archives and } \\
\text { Manuscripts }\end{array}$ & $52.1 \% ;$ & $\mathrm{C}$ & $\mathrm{A}$ \\
\hline Archivaria & $35.8 \% ;$ & Not listed & Not listed \\
\hline $\begin{array}{l}\text { Society of Archivists } \\
\text { Journal }\end{array}$ & $33.9 \% ;$ & $\mathrm{A}^{*}$ & $\mathrm{~A}$ \\
\hline American Archivist & $31.9 \% ;$ & Not listed & Not listed \\
\hline $\begin{array}{l}\text { Information } \\
\text { Management Journal }\end{array}$ & $30.7 \%$ & $\mathrm{C}$ & $\mathrm{A}$ \\
\hline $\begin{array}{l}\text { Records Management } \\
\text { Journal }\end{array}$ & $30.7 \% ;$ & Not listed & Not listed \\
\hline Archifacts & $28.9 \% ; ;$ & A* & A* \\
\hline Archival Science & $18.4 \% ;$ & Not listed & Not listed \\
\hline $\begin{array}{l}\text { Information \& } \\
\text { Management }\end{array}$ & $17.9 \%$ & & \\
\hline
\end{tabular}


The data in Table 5 above are indicative of the similarity in appreciation of journals between the different information professions and also indicate the crossover of interests between them. Two of the titles appear in the Australian ERA LIS listing as A* titles, there are 3 Tier $C$ titles and 4 of the titles were not listed on the ALIA list. While the tier listings for some of the titles is different in the final ARC/ERA 2010 list, the congruence of titles for 0807 and records managers remains similar to that demonstrated in the ALIA list. That the LIS and archival professions appear in a different FoR than records managers remains an anomaly for these discipline areas.

Time will tell if the location of Australian LIS under the FoR 08: Information and Computing Sciences, which includes Library and Information Studies under the code 0807 will be detrimental to the representation of LIS in Australia's research outputs and outcome measures. The FoR codes were established as a "means of classifying research for government policy and they were not originally intended to be used for classifying publications" (Edwards as quoted by Rowbotham, 2010, p. 39). If this remains the case, then the categorization of the archival journal titles in FoR 0807, when the Australian Bureau of Statistic's document specifically states that "e) Archival, repository and related studies is included in Group 2102 Curatorial and Related Studies” (ABS, 2008, n.p.), makes some sense. It remains to be seen how the dual categorisation of archives and related studies will work in practice, and how librarianship, for which strong cultural and community research aspects can be demonstrated amongst many, will fit in 0807 .

Assuming, perhaps boldly, that the Australian 0807 title recommendations are accepted in total, the next step will be to ensure that most if not all are indexed by Scopus, since Scopus has been accepted by the ARC as the citation supplier for full citation evaluations (ARC, 2009c). Since Australian library and information studies research is captured under the broader FoR of 08 - Information and Computing Sciences, the assessment of the 0807 research capability appears to be according to the rules for 08 .

\section{Conclusion}

The momentum for the journal ranking exercise started for the Australian LIS community with the RQF in 2007. The work galvanised the Australia LIS researcher and academic community into thinking about relevant journal titles, ensuring that the titles they choose to publish in are refereed, and also ensuring that the few titles that emanate from Australia are supported and recognised.

All of this work was undone by a comprehensive press release on improvements to ERA by the Minister for Innovation, Industry, Science and Research on 30 May 2011: "I have made the decision to remove rankings [of journals] based on the ARC's expert advice" (Carr, 2011, p. 2). The same press statement hinted at a number of "improvements" and these are now awaited.

\section{References}

Australian and New Zealand Standard Research Classification (ANZSRC) (2008). Retrieved from 
http://www.abs.gov.au/AUSSTATS/abs@.nsf/Latestproducts/4C3249439D3285D6CA25 7418000470E3?opendocument

Australian Bureau of Statistics (ABS). (2008). 1297.0 - Australian and New Zealand Standard Research Classification (ANZSRC). Retrieved from http://www.abs.gov.au/ausstats/abs@.nsf/0/869D435B896AFBE6CA25741800047622? opendocument

Australian Research Council (ARC). (2009a, March). Physical, Chemical and Earth Sciences (PCE) and Humanities and Creative Arts (HCA) clusters: ERA submission guidelines. Retrieved from http://www.arc.gov.au/era/trial.htm

Australian Research Council (ARC). (2009b). Tiers for the Australian ranking of journals. Retrieved from http://www.arc.gov.au/era/tiers_ranking.htm

Australian Research Council (ARC). (2009c). Citation supplier announced. ERA News, November 2009. Retrieved from: http://www.arc.gov.au/era/era_news.htm

Australian Research Council (ARC). (2010, October). Review of the ERA 2010 ranked outlet lists. ERA News, p. 1.

Butler, L. (2003, a) .Modifying publication practices in response to funding formulas. Research Evaluation. 12(1), 39-46, as cited by Willard, Kennan, Wilson \& White (2008).

Butler, L. (2003, b). Explaining Australia's increased share of TS publications: The effects of a funding formula based on publication counts. Research Policy. 32, 143-155, as cited by Willard, Kennan, Wilson \& White, (2008).

Calder, A. (2009, December 17). CONFIDENTIAL - Full Draft Journal List - for review. Email to reviewers.

Carr, K. (Senator). (2011, May 30). Ministerial statement to the Senate Economics Legislation Committee Improvements to Excellence in Research for Australia (ERA). Retrieved from:

http://minister.innovation.gov.au/carr/mediareleases/pages/improvementstoexcellenceinre searchforaustralia.aspx

Clunies Ross, M. (2008, February 6). One size can’t fit all researchers. The Australian: Higher Education, p. 26.

Cockbain, T. (2010, March). Journal ranking. The Australian Geologist, p. 6

Computing Research and Education Association (CoRE). (2009). Retrieved from: http://www.core.edu.au 
Cowan, R. \& Pember, M. (2008, February). The top ten professional journals read by recordkeeping practitioners in Australasia. Informaa Quarterly (IQ), 42-47.

Drummond, R. \& Wartho, R. (2009, June). RIMS: The research impact measurement service at the University of New South Wales. AARL. 40(2), 76-87.

Excellence In Research Australia (ERA). (2009). Retrieved from http://www.arc.gov.au/era

Haddow, G., \& Genoni, P. (2009, June). Australian education journals: Quantitative and qualitative indicators. Australian Academic \& Research Libraries (AARL), 40(2), 88104.

Healy, G. (2008, August 13). Jai Tong top 100 slot for Sydney. The Australian: Higher Education, p. 25.

Rowbotham, J. (2010, November 10). Journal rankings rankle academics. The Australian, Higher Education Supplement, p. 39.

Searle, S. (2009, September). Managing research data: a new direction for university libraries. inCite. 30 (9), 27-8.

Smith, K. (2004). Performance measurement of Australian geoscientific minerals researchers in the changing funding regimes. PhD thesis. Murdoch University. Retrieved October 2009 from http://wwwlib.murdoch.edu.au/adt/browse/list/S-Z

Smith, K. \& Marinova, D. (2003a). Bibliometrical modeling and policy making. In Post, D. (Ed.). Modelling and simulation Society of Australia and New Zealand Inc. MODSIM 2003: International Congress on Modelling and Simulation: Integrative modeling of biophysical, social and economic systems for resource management solutions. Canberra: The Society. pp. 1177-1182.

Smith, K. \& Marinova, D. (2003b). Academic publishing in the Australian changing funding environment: an analysis of journal ranking in the geosciences. In Post, D. (Ed.). Modelling and simulation Society of Australia and New Zealand Inc. MODSIM 2003: International Congress on Modelling and Simulation: Integrative modeling of biophysical, social and economic systems for resource management solutions. Canberra: The Society. pp. 1200-1205.

Smith, K. \& Middleton, M. (2009, March) Australian library \& information studies (LIS) researchers' ranking of LIS journals. Australian Academic \& Research Libraries (AARL), 1-20.

Ulrich's periodicals directory [electronic resource]. [New Providence, N.J.] : R.R. Bowker ; [East Grinstead : Bowker] retrieved from Ulrichsweb.com [electronic resource] 
Willard, P., Kennan, M.A., Wilson, C.S. \& White, H.D. (2008, June). Publication by Australian LIS academics and practitioners: a preliminary investigation. Australian Academic \& Research Libraries (AARL). 39 (2), 65-78. 